\title{
Phase Transformation and Grain Coarsening of Zirconia/Mullite Composites
}

\author{
Wen-Cheng J. Wei, H. C. Kao \& M. H. Lo \\ Institute of Materials Science and Engineering, National Taiwan University, Taipei, Taiwan 106, Republic of China
}

(Accepted 22 July 1995)

\begin{abstract}
$\mathrm{ZrO}_{2}$ /mullite composites ( $\mathrm{ZMC}$ ) with homogeneously dispersed $\mathrm{ZrO}_{2}$ grains were prepared from colloidal or sol-gel processes of the precursors, which were a mixture of colloidal pseudo-boehmite $(\gamma-A l O O H)$, zirconia and silicic acid gel, or prepared from dissociated zircon with alumina powder. After pressureless sintering of the ZMCs, their microstructure was examined by means of $X$-ray diffractometry, scanning electron microscopy and analytical transmission electron microscopy techniques. The microstructure of the ZMCs showed a difference in scale. $\mathrm{ZrO}_{2}$ and mullite grains grown in the gel matrix were formed at temperatures as low as 1100 and $1300^{\circ} \mathrm{C}$, respectively. Experimental results indicated that heat treatment from 1300 to $1600^{\circ} \mathrm{C}$ influences the growth of mullite and fine $\mathrm{ZrO}_{2}$ grains in $\mathrm{ZMCs}$, especially for the composite prepared from sol-gel methods in which the $\mathrm{ZrO}_{2}$ grew from tens of nanometres to micrometre size. The effects of the presence of ultra-fine $\mathrm{ZrO}_{2}$ on retarding the grain growth of mullite and the increase of metastable t-phase $\mathrm{ZrO}_{2}$ are also discussed. The growth of fine $\mathrm{ZrO}_{2}$ grains in a mullite matrix belongs to a mechanism of coalescence.
\end{abstract}

\section{Introduction}

The appropriate selection of a matrix phase and the addition of various zirconia grains to form ceramic composites with better strength and toughness has become widely recognised as a method for producing materials for engineering applications. $\mathrm{ZrO}_{2}$ in alumina, ${ }^{1} \mathrm{Si}_{3} \mathrm{~N}_{4}{ }^{2}$ and mullite have been reported to form composite systems that are effective in strengthening and toughening the ceramic matrix. Garvie ${ }^{4}$ also found that the addition of $10 \%$ tetragonal $(t)$ zirconia enhanced the thermal shock resistance of zircon-zirconia composite. The retained strength of zirconiazircon composites could be as high as $90 \%$ of the original after quenching from $600^{\circ} \mathrm{C}$. In addition, other advantages included less deterioration as a result of the tetragonal to monoclinic $(m)$ phase transformation of zirconia grains at high temperature and in high humidity environment, and more economically feasible materials owing to lower costs. However, some disadvantages were also recognised: the zirconia particles coarsened in the alumina matrix ${ }^{5}$ as soon as the ceramic matrix densified. Also, thermal expansion mismatch of $\mathrm{ZrO}_{2}$ with the ceramic matrix resulted in thermal stresses, either tensile or compressive, as the zirconia composite was cooled from sintering temperature. These would trigger the ' $t$-to- $m$ ' transformation, thereby degrading mechanical properties.

High quality mullite can be made from various sources, alkoxides or other high purity chemicals, through the sol-gel or co-precipitation method. ${ }^{6}$ The method allows the addition of zirconia for making zirconia-toughened mullite (called ZMC in this paper) composites. In addition, the composites can also be made by the reaction sintering of zircon and alumina, ${ }^{7,8}$ by the co-sintering of fine zirconia/mullite mixture, ${ }^{9}$ or by directly sintering the mixture of alumina, silica and zirconia.

High temperature densification above $1450^{\circ} \mathrm{C}$ with sintering aids is currently used to densify the zirconia-mullite composite. $\mathrm{TiO}_{2},{ }^{3} \mathrm{MgO}^{10,11}$ and $\mathrm{Ca}^{12}$ can facilitate the formation of a liquid phase to achieve viscous sintering. These additives were reported to have a profound influence on the high temperature properties of $Z M C^{8}$ and on the formation of glassy and grain boundary phases. ${ }^{10}$

The additives, including $\mathrm{ZrO}_{2}$ and sintering aids, may dissolve in the mullite matrix to some extent. A microanalysis experiment to determine the $\mathrm{ZrO}_{2}$ content in mullite grains was conducted by Dinger et al.,$^{13}$ who found the presence of an apparent solid solution on the crust of mullite grains. This gave a grain boundary of mullite in a state of expansion, thereby improving the toughness of the composite. Other oxide dopants, including $\mathrm{Ti}, \mathrm{V}, \mathrm{Mn}, \mathrm{Fe}$ and $\mathrm{Co}$ oxides, ${ }^{14}$ incorporated into 
the mullite structure were determined as being preferentially located in oxygen octahedral sites. The upper limit of solubility is controlled by cation radii and the valence state of cations. This work was partially motivated by the report that the amount of $\mathrm{ZrO}_{2}$ solid solution in mullite composites was of the order of few per cent up to $20 \%,{ }^{13}$ which was thought to be quite influential in determining the grain growth mechanism of $\mathrm{ZrO}_{2}$.

Since the toughness and high temperature stability of ZMC are dependent upon the reactions between zirconia and mullite phases, gel-derived precursors and high purity zircon reacted with alumina are used here with and without sintering additives. This research attempts to characterize the transformation of $\mathrm{ZrO}_{2}$ and the microstructural features, as well as determine the coarsening phenomenon of zirconia and mullite. Thus, rationalizing the parameters which govern the grain growth phenomenon is of interest, thereby permitting the development of an appropriate quantitative model.

\section{Experimental}

\subsection{Sample preparation}

\subsubsection{Gel-derived (GD-) ZMC}

The solution prepared for gelation included 50 wt $\%$ tetraethyl orthosilicate (TEOS; Merck Chemical Co., Germany), $30 \mathrm{wt} \%$ dry alcohol (reagent grade; Showa Chemicals Co., Ltd, Tokyo, Japan) and $20 \mathrm{wt}^{\circ} \% 0.018 \mathrm{~N} \mathrm{HCl}$ (diluted from regent grade $0.1 \mathrm{~N} \mathrm{HCl}$; Merck Chemical Co., Germany). The three chemicals were first mixed and then maintained in a water bath at $50^{\circ} \mathrm{C}$ for $3 \mathrm{~h}$, so as to obtain a well-mixed silicic acid solution. ${ }^{6}$ Next, pseudo-boehmite sol (Remet Co., NY, USA) and $\mathrm{ZrO}_{2}$ sol (Johnson Matthey Co., MA, USA) were slowly added to the solution. After mixing for $30 \mathrm{~min}$, the viscosity of the solution increased until gelation. The gel was dried at $80^{\circ} \mathrm{C}$ for several days until no further weight loss was measured. The aerogel was crushed and sieved through 325 mesh. The $\mathrm{Al}_{2} \mathrm{O}_{3}$ and $\mathrm{SiO}_{2}$ ratio was at the mullite stoichiometry and the volume fraction of added $\mathrm{ZrO}_{2}$ was 24,9 or $3 \mathrm{vol} \%$. ZMC powders were die-pressed at a pressure of 160 $\mathrm{MPa}$. Sintering of the specimens was conducted at 800 to $1600^{\circ} \mathrm{C}$ for 2 to $6 \mathrm{~h}$.

\subsubsection{Reaction-sintered ( $R S$-) $Z M C$}

Two types of RS-ZMC mixture were selected as comparative cases. ${ }^{15}$ One was a mixture of dissociated zircon (supplied by Z-Tech Corp.; impurities included $0.36 \% \mathrm{Al}_{2} \mathrm{O}_{3}, 0.08 \% \mathrm{TiO}_{2}, 0.03 \% \mathrm{Fe}_{2} \mathrm{O}_{3}$, and $0.11 \%$ free $\mathrm{SiO}_{2}$ ) and alumina (A-16SG; Alcoa
Corp., USA) powders. The other consisted of ground zircon sand, alumina and $4 \mathrm{wt} \% \mathrm{CeO}_{2}$ as a sintering aid. They are named DZ-ZMC and $\mathrm{RS}\left(\mathrm{CeO}_{2}\right)-\mathrm{ZMC}$, respectively. The zircon/alumina mixtures were in a molar ratio of $2: 3$, subsequently yielding $24 \mathrm{vol} \% \mathrm{ZrO}_{2}$. These powders were initially dispersed in distilled water with 1 wt $\%$ dispersant (based on solid phase; Darvan C, supplied by R.T. Vanderbilt Co., USA), then turbo-mixed for $2 \mathrm{~h}$. The solid fraction of the slurry was $30 \mathrm{vol} \%$. After being cast and dried on a plaster mould, the $\mathrm{CeO}_{2}$-doped $\mathrm{RS}-\mathrm{ZMC}$ was sintered between 1400 to $1550^{\circ} \mathrm{C}$ for $2 \mathrm{~h}$; however, the DZ-ZMC was sintered at higher temperatures, from 1400 to $1700^{\circ} \mathrm{C}$ (which is higher than the dissociation temperature of zircon) for $30 \mathrm{~min}$. The heating rate of the sintering was $10^{\circ} \mathrm{C} \mathrm{min}^{-1}$. Nearly fully-dense DZ-ZMC and RS-ZMC samples were obtained, then heat-treated at temperatures from 1400 to $1700^{\circ} \mathrm{C}$.

\subsection{Characterization}

Densification of the ZMCs was examined by a dilatometer (Theta Industries, Inc., USA) up to $1500^{\circ} \mathrm{C}$. Crystalline phases were determined by X-ray diffractometry (XRD; PW 1729, Philips Electronics Instruments, Inc., USA). Microstructural and micro-chemical analyses were performed by using scanning electron microscopy (SEM; Philips 515) and transmission electron microscopy (TEM; JEOL 100CXII and 2000FX, JEOL Inc., Japan), the latter equipped with EDAX (Tracer Northan Co., USA). The densities of the sintered specimens were obtained by Archimedes' method.

\section{Results and Discussion}

\subsection{Transformation sequence}

The XRD patterns of three ZMC powders were analysed and are summarized in Table 1. GDZMC appeared to have no crystalline phases when sintered at $800^{\circ} \mathrm{C}$ for $2 \mathrm{~h}$. Tetragonal $-\mathrm{ZrO}_{2}$ and mullite phases appeared at 1100 and $1300^{\circ} \mathrm{C}$, respectively. The peak width of the $t$-phase $\mathrm{ZrO}_{2}$ at $1100^{\circ} \mathrm{C}$ in Fig. 1 is apparently broader than the diffraction peaks of $t-\mathrm{ZrO}_{2}$ at temperatures $\geq 1200^{\circ} \mathrm{C}$. This implies that the zirconia has a fine grain size. After sintering at temperatures of $1600^{\circ} \mathrm{C}$ or above, a large portion of $\mathrm{ZrO}_{2}$ transforms to $m$-phase in the GD-ZMC. As for the $\mathrm{RB}-\mathrm{ZMC}$, only about one-third of the $\mathrm{ZrO}_{2}$ was found to be the tetragonal phase at sintering temperatures above $1450^{\circ} \mathrm{C}$, but this quantity decreased with increasing sintering temperature and $\mathrm{CeO}_{2}$ additive, as shown in Fig. 2. This decrease could be due to grain growth of the 
Table 1. Phases detected in ZMCs prepared from three different sources and sintered at temperature shown for $2 \mathrm{~h}$

\begin{tabular}{|c|c|c|c|c|c|c|c|}
\hline \multicolumn{8}{|l|}{$G D-Z M C$} \\
\hline Zircon & 1000 & - & $*$ & $*$ & $*$ & 1300 & $1000(2)$ \\
\hline Mullite & - & - & - & $*$ & $*$ & $*$ & $*$ \\
\hline$t-\mathrm{ZrO}_{2}$ & $* *$ & ** & $* *$ & $* *$ & $* *$ & * & $*$ \\
\hline$m-\mathrm{ZrO}_{2}$ & - & - & - & - & - & $*$ & $* *$ \\
\hline \multicolumn{8}{|c|}{$R S-Z M C($ without additive $)$} \\
\hline phase/temp. & 1400 & 1450 & 1500 & $1550\left({ }^{\circ} \mathrm{C}\right)$ & & & \\
\hline Zircon & $* *$ & $* *$ & $*$ & $*$ & & & \\
\hline Mullite & - & - & $*$ & $*$ & & & \\
\hline$t-\mathrm{ZrO}_{2}$ & - & - & * & $*$ & & & \\
\hline$m-\mathrm{ZrO}_{2}$ & - & 一 & $*$ & $* *$ & & & \\
\hline \multicolumn{8}{|c|}{$\mathrm{RS}-\mathrm{ZMC}$ (with $4 \mathrm{wt} \% \mathrm{Ce} \mathrm{O}_{2}$ additive) } \\
\hline phase/temp. & 1400 & 1450 & 1500 & $1550\left({ }^{\circ} \mathrm{C}\right)$ & & & \\
\hline Zircon & $* *$ & $*$ & $*$ & $*$ & & & \\
\hline Mullite & - & * & * & * & & & \\
\hline$t-\mathrm{ZrO}_{2}$ & - & - & * & - & & & \\
\hline$m-\mathrm{ZrO}_{2}$ & - & * & * & $* *$ & & & \\
\hline
\end{tabular}

Note,$-{ }^{*}$ and ${ }^{* *}$ means that the X-ray diffraction intensity of the phase is not detectable, detectable and in large quantity, respectively.

$\mathrm{ZrO}_{2}$, lack of phase stabilizer such as $\mathrm{CaO}$ or $\mathrm{MgO}$, and thermal stress induced transformation. However, the amount of $t-\mathrm{ZrO}_{2}$ finally became stable at a level of $20 \%$ (Fig. 2) when the heat treatment was extended up to $4 \mathrm{~h}$ at $1450^{\circ} \mathrm{C}$. This occurrence is explained later by means of microstructural observations (in Section 3.3), in which the $t-\mathrm{ZrO}_{2}$ is possibly intragranular and holds a submicrometre size.

The formation temperatures of these zirconia and mullite phases in GD-ZMC are apparently lower than the RS-ZMCs, as shown in Table 1, and are also lower than those reported by Low and McPersonal. ${ }^{16}$ GD-ZMC underwent this transformation at a temperature $200^{\circ} \mathrm{C}$ lower than that for RS-ZMC. ${ }^{17}$ This lower transformation is due to the reaction kinetics, enhanced by the fact of the diminutive gel structure in GD-ZMC.

Zircon, as a reaction product of zirconia and silica, forms as a transition phase in the gel-

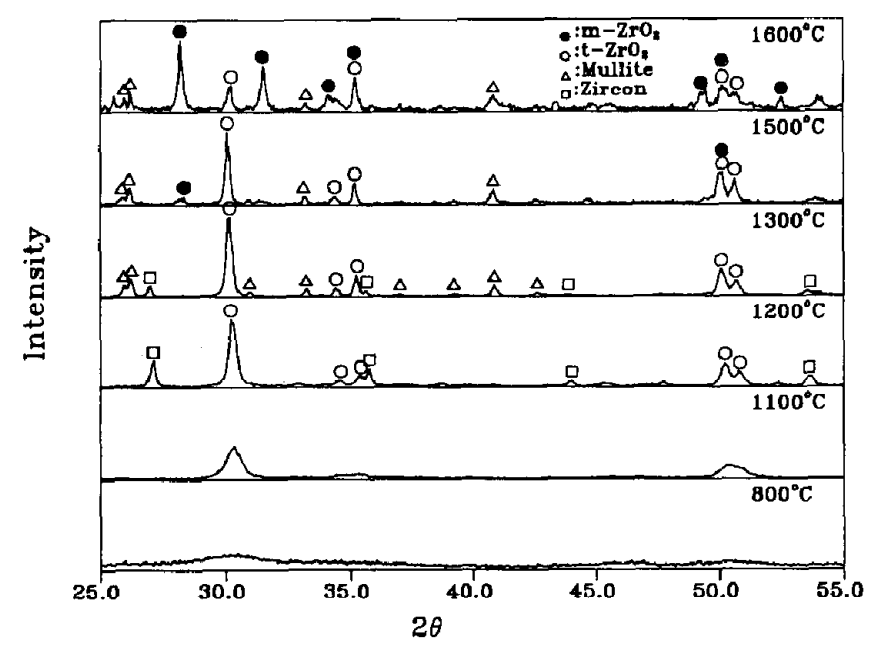

Fig. 1. XRD patterns for GD-ZMC samples after sintering at 800 to $1600^{\circ} \mathrm{C}$ for $2 \mathrm{~h}$. derived $\mathrm{ZMC}$ in the range between 1200 and $1500^{\circ} \mathrm{C}$. If the temperature increases, the amount of zircon phase decreases and is accompanied by the appearance of mullite phase. The formation and diminishing of zircon phase in a similar ZMC
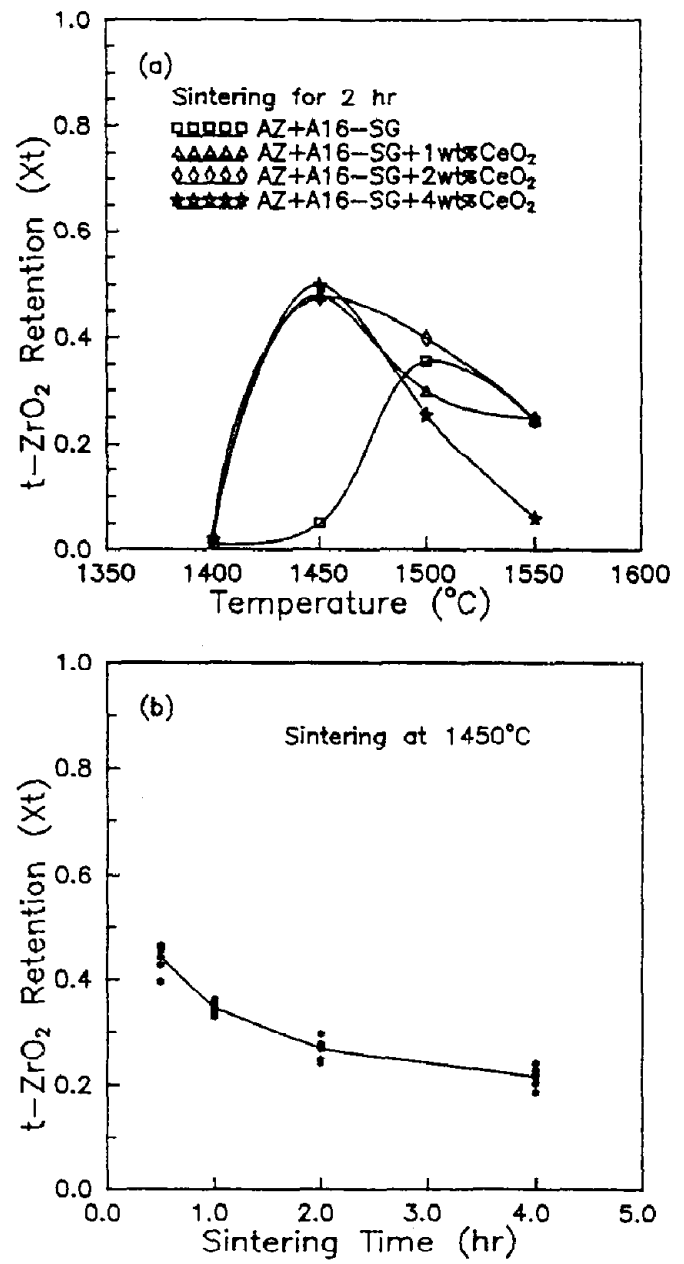

Fig. 2. Weight fraction of $t$-phase zirconia in reactionsintered RS- $\left(\mathrm{CeO}_{2}\right)-\mathrm{ZMC}$ as a function of (a) sintering temperature and (b) sintering time at $1450^{\circ} \mathrm{C}$. 
was also reported by Holmstron et al. ${ }^{18}$ who used $\mathrm{Al}_{2} \mathrm{O}_{3}, \mathrm{SiO}_{2}$ and $\mathrm{ZrO}_{2}$ as raw materials to prepare a reaction-sintered $\mathrm{ZMC}$. The zircon appeared at temperatures between $1450-1560^{\circ} \mathrm{C}$ when the $\mathrm{ZrO}_{2}$ content was $>15 \mathrm{vol} \%$. In this study, the spray-dried powders were found to have phase transformation sequences similar to those of the powders prepared from grinding.

\subsection{Densification of ZMCs}

Dilatometric data of the ZMCs are shown in Fig. 3 plotted as a function of sintering temperature up to $1500^{\circ} \mathrm{C}$. The changes in the dimensions of die-pressed GD-ZMC at temperatures around 300 and $550^{\circ} \mathrm{C}$ correspond to the sintering of extremely fine pores, in which the contained volatile species evaporate readily. Those $\mathrm{nm}$ size pores are densified at $600^{\circ} \mathrm{C}$ or lower temperatures, as reported previously. ${ }^{6}$ Testing at higher temperature unveils that the next densification of GD-ZMC starts at $900^{\circ} \mathrm{C}$ and exhibits the fastest densification rate at $1200^{\circ} \mathrm{C}$. In comparison, DZ- or RS-ZMC specimens undergo less densification and at higher temperature starting from $1100^{\circ} \mathrm{C}$. The densification rate of RS-ZMC can be enhanced by the addition of $\mathrm{CeO}_{2}$, as revealed by the densification curve of the $\mathrm{RS}\left(\mathrm{CeO}_{2}\right)-\mathrm{ZMC}$ in Fig. 3. The GD-ZMC shows a lower sintering temperature and more shrinkage than the other two ZMCs.

\subsection{Microstructural evolution}

Figure 4 shows SEM micrographs of polished and thermally-etched RS- and DZ-ZMC samples. The micrographs show dense and well reacted ZMCs, which have a relative density of $>95 \%$ TD (theoretical density). The densified ZMCs show very stable microstructural features, most of the intergranular $\mathrm{ZrO}_{2}$ being $3 \mu \mathrm{m}$ in size (Fig. 5), as they are post-annealed at temperatures of 1400 to

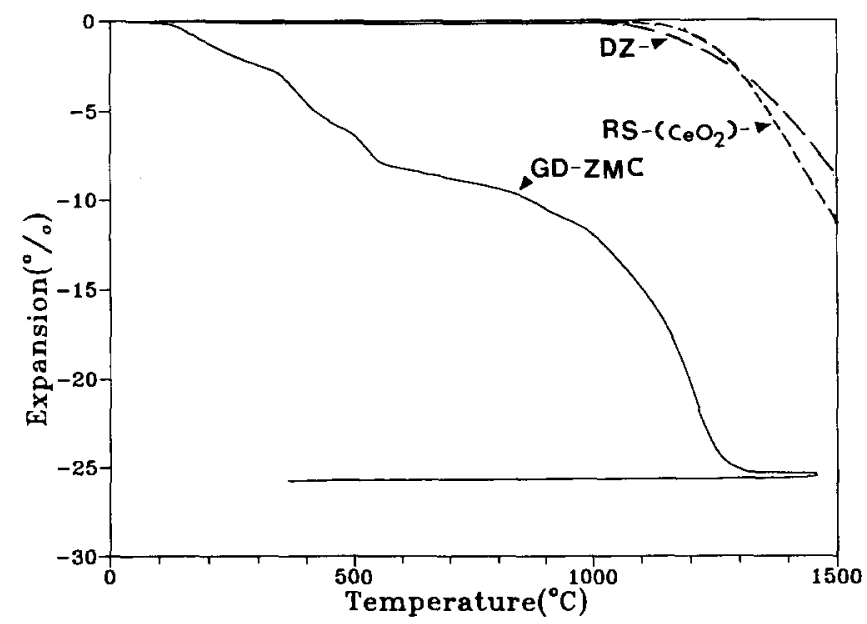

Fig. 3. Dilatometric curves of gel-derived (GD), reactionsintering with $4 \mathrm{wt} \% \mathrm{CeO}_{2}\left(\mathrm{RS}-\left(\mathrm{CeO}_{2}\right)\right.$-) and DZ-ZMC specimens plotted as a function of temperature.
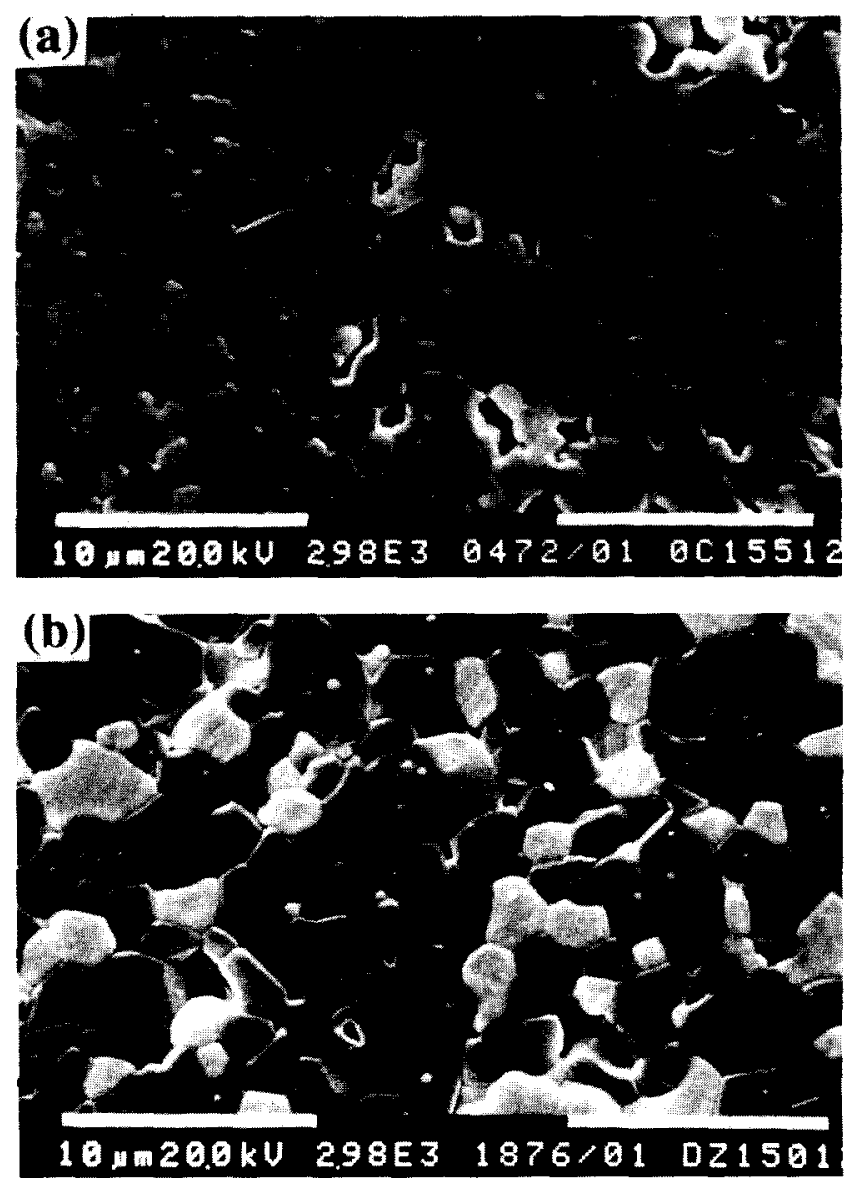

Fig. 4. SEM micrographs of (a) RS-ZMC without doping additive sintered at $1550^{\circ} \mathrm{C}$ for $12 \mathrm{~h}$; (b) DZ-ZMC sintered at $1700^{\circ} \mathrm{C}$ for $30 \mathrm{~min}$, then annealed at $1500^{\circ} \mathrm{C}$ for $12 \mathrm{~h}$. The samples were all polished and thermally etched.

$1600^{\circ} \mathrm{C}$ for up to $24 \mathrm{~h}$. The grain sizes of mullite and $\mathrm{ZrO}_{2}$ change within the range of experimental error, so that their grains are considered not to coarsen during the heat treatment. Some fine and submicrometre-sized zirconia grains are observed

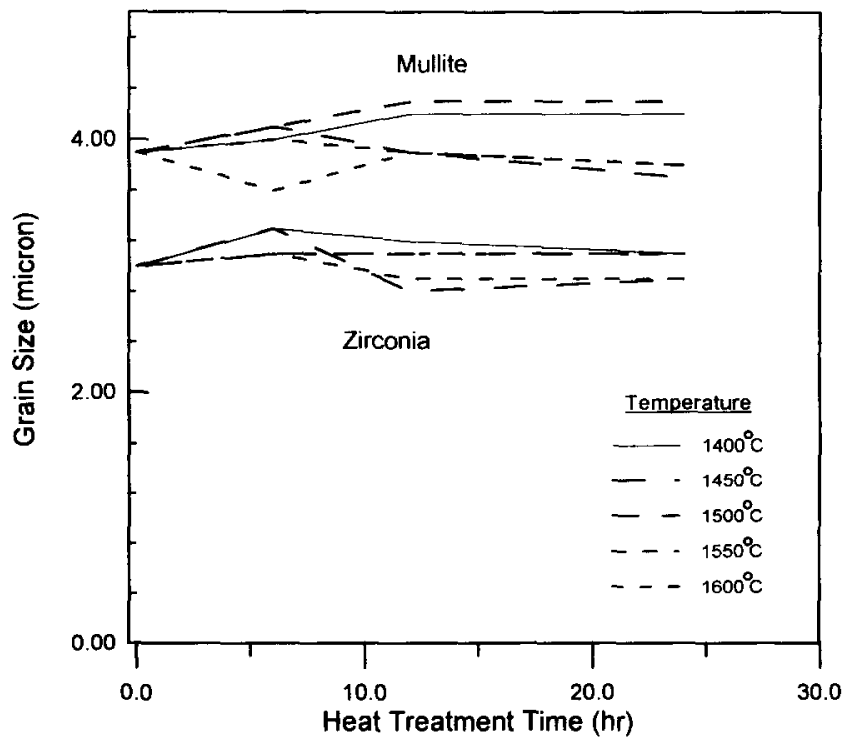

Fig. 5. Average grain sizes $(\mu \mathrm{m})$ of intergranular zirconia and mullite grains of DZ-ZMC samples with $24 \mathrm{vol} \% \mathrm{ZrO}_{2}$ sintered at $1700^{\circ} \mathrm{C}$ for $30 \mathrm{~min}$ following various heat treatments. 


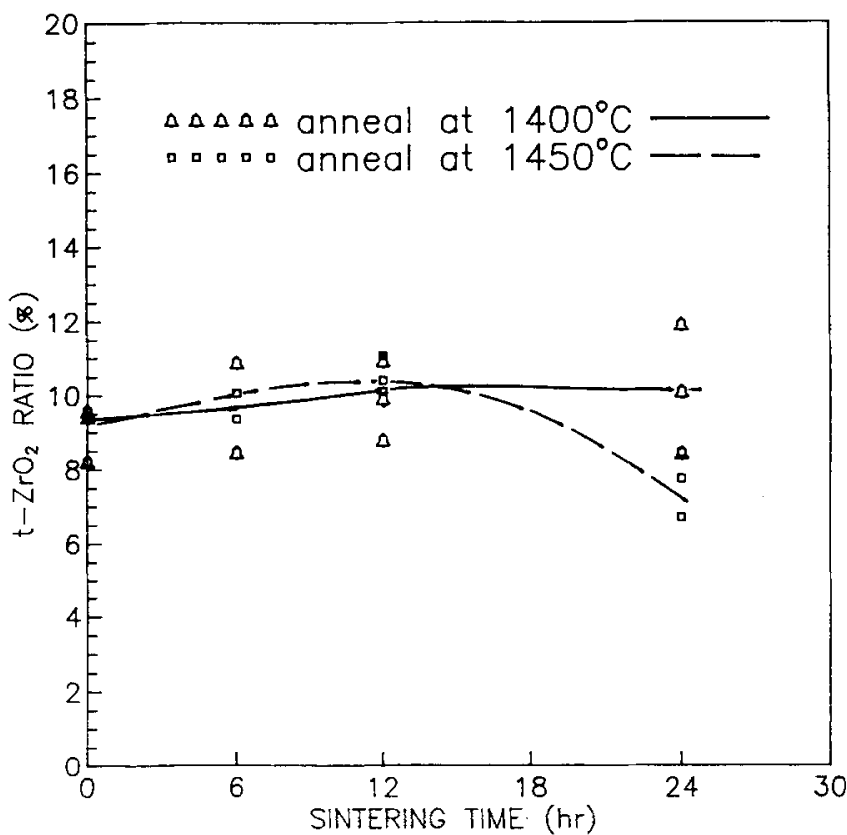

Fig. 6. Weight percentage of $t-\mathrm{ZrO}_{2}$ phase to all $\mathrm{ZrO}_{2}$ in $\mathrm{DZ}$ $\mathrm{ZMC}$ vs. annealing period at 1400 or $1450^{\circ} \mathrm{C}$.

that are nearly spherical and engulfed in mullite grains (Fig. 4). These intragranular $\mathrm{ZrO}_{2}$ grains are the major part of $t$-phase $\mathrm{ZrO}_{2}$ which is not transformable even following the same postannealing at 1400 or $1450^{\circ} \mathrm{C}$ as long as $24 \mathrm{~h}$ (Fig. 6). The microstructures of the RB-ZMCs are stable at high temperatures $\left(>1400^{\circ} \mathrm{C}\right)$. However, the reaction-sintering process for the preparation of $\mathrm{ZMC}$ cannot offer the microstructure with finer $\mathrm{ZrO}_{2}$ and submicrometre-sized mullite grains.

GD-ZMC samples sintered at 1400,1500 or $1600^{\circ} \mathrm{C}$ for $2 \mathrm{~h}$ were carefully polished and thermally-etched at the conditions $1350^{\circ} \mathrm{C}$ for $2 \mathrm{~h}$, $1475^{\circ} \mathrm{C}$ or $1500^{\circ} \mathrm{C}$ for $30 \mathrm{~min}$, respectively. The GD-ZMC sample sintered at $1600^{\circ} \mathrm{C}$ [Fig. 7(c)] has a similar microstructure to the previous RSZMCs. A small fraction of fine-grained zirconia is enclosed in the mullite grains, which are of the order of a few micrometres in size. Figures $7(\mathrm{~b})$ and (c) clcarly show that $\mathrm{ZrO}_{2}$ grains are either intergranular or intragranular; the grain size of intergranular $\mathrm{ZrO}_{2}$ increasing with sintering temperature. The intragranular $\mathrm{ZrO}_{2}$ in the $1400^{\circ} \mathrm{C}$ and $2 \mathrm{~h}$ sintered sample is $<0.1 \mu \mathrm{m}$. If sintered at $1600^{\circ} \mathrm{C}$ for $2 \mathrm{~h}$, it grows to $2.3 \mu \mathrm{m}$ and becomes intergranular. Increasing the size of $\mathrm{ZrO}_{2}$ grains has been shown previously to instantly transform $\mathrm{ZrO}_{2}$ to $m$-phase. ${ }^{5}$ The analysis of XRD patterns in Fig. 1 reveals several strong diffraction peaks of the $m$-phase in the pattern of the $1600^{\circ} \mathrm{C}$ sintered samples; however, the $m$-phase is rarely detected in the GD-ZMC processed at $1500^{\circ} \mathrm{C}$ or lower temperatures.

It is noted that the amount of intragranular $\mathrm{ZrO}_{2}$ decreases with increasing sintering tempera-
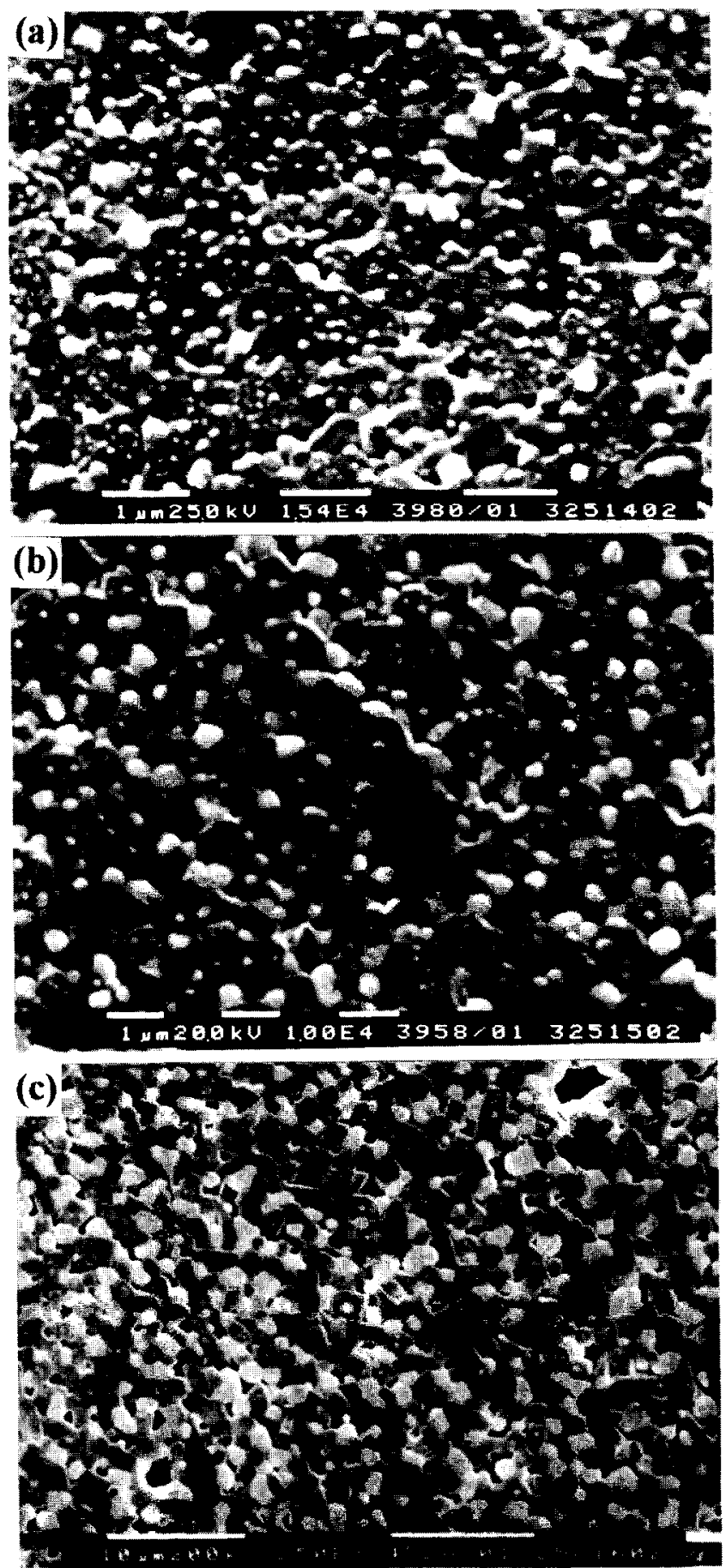

Fig. 7. SEM micrographs of polished and thermally etched GD-ZMC specimens sintered at (a) $1400^{\circ} \mathrm{C}$, (b) $1500^{\circ} \mathrm{C}$ and (c) $1600^{\circ} \mathrm{C}$ for $2 \mathrm{~h}$.

ture. Meanwhile, the average grain sizes of the intergranular $\mathrm{ZrO}_{2}$ and matrix mullite grow larger. The grain size data, obtained from SEM and TEM micrographs, reveal that the intergranular $\mathrm{ZrO}_{2}$ and matrix mullite grains scarcely grow from 1300 to $1500^{\circ} \mathrm{C}$. However, both phases grow rapidly in size when the sintering temperature rises from 1500 to $1600^{\circ} \mathrm{C}$.

TEM bright-field (BF) and centred-dark-field (CDF) micrographs of a GD-ZMC sample sintered at $1300^{\circ} \mathrm{C}$ for $2 \mathrm{~h}$ are shown in Fig. 8. The $\mathrm{BF}$ image shows that the $\mathrm{ZrO}_{2}$ grains in dark 


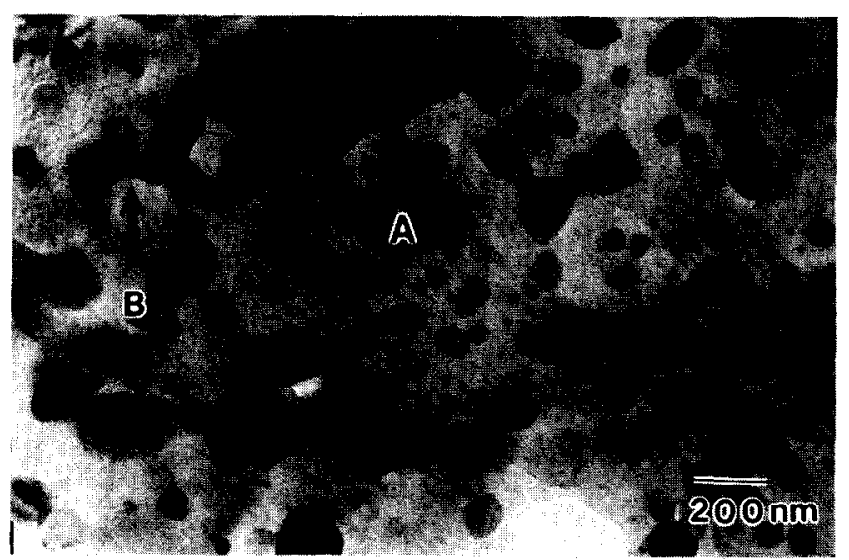

Fig. 8. TEM BF micrograph of GD-ZMC (with $24 \mathrm{vol} \% \mathrm{ZrO}_{2}$ ) sintered at $1300^{\circ} \mathrm{C}$ for $2 \mathrm{~h}$.

contrast are uniformly dispersed within the mullite matrix. For sintering at higher temperature, a few large $\left(0.3 \mu \mathrm{m}\right.$ or larger) intergranular $\mathrm{ZrO}_{2}$ grains are occasionally found in the $1400^{\circ} \mathrm{C}$ sintered GDZMC. The twinning features of these grains (Fig. 9) are characteristic of $m$-phase $\mathrm{ZrO}_{2}$. The boundaries of each $\mathrm{ZrO}_{2}$ lath in the large $m-\mathrm{ZrO}_{2}$ grains exhibit interfacial microcracks, as denoted by arrows A and B in Fig. 9. In addition to the microcracks, strain fringes (arrow $C$ ) occurring next to large $\mathrm{ZrO}_{2}$ grains are produced by thermal mismatch, and represent internal stresses. ${ }^{19}$ These features, i.e. microcracks and strain fringes, are possibly caused by the phase transformation of $t-\mathrm{ZrO}_{2}$ to $m-\mathrm{ZrO}_{2}$ and thermal expansion mismatch between mullite and $\mathrm{ZrO}_{2}$.

SEM and TEM analyses indicate that GDZMC has a smaller grain size than DZ- or RS$\mathrm{ZMC}$ when sintering at the same temperature. For $24 \mathrm{vol} \% \mathrm{ZrO}_{2}$ samples, the average grain size of the intergranular $\mathrm{ZrO}_{2}$ in GD-ZMC is $98 \mathrm{~nm}$ and the size of the mullite grains is $600 \mathrm{~nm}$, which is

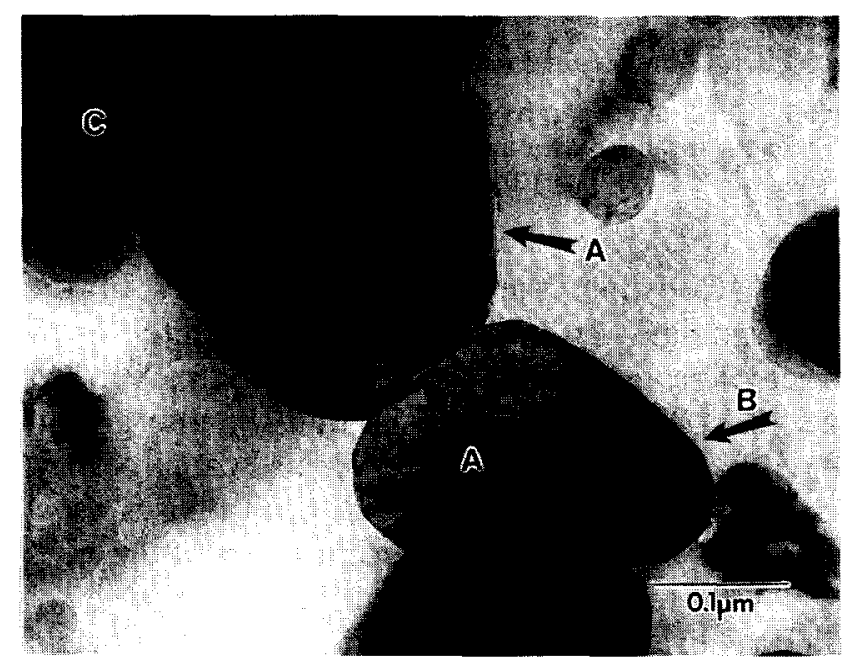

Fig. 9. Microcracks (A and B) and strain fringes (C) around two overgrowth $m-\mathrm{ZrO}_{2}$ grains, imaged with TEM BF conditions. The GD-ZMC was sintered at $1400^{\circ} \mathrm{C}$ for $2 \mathrm{~h}$.
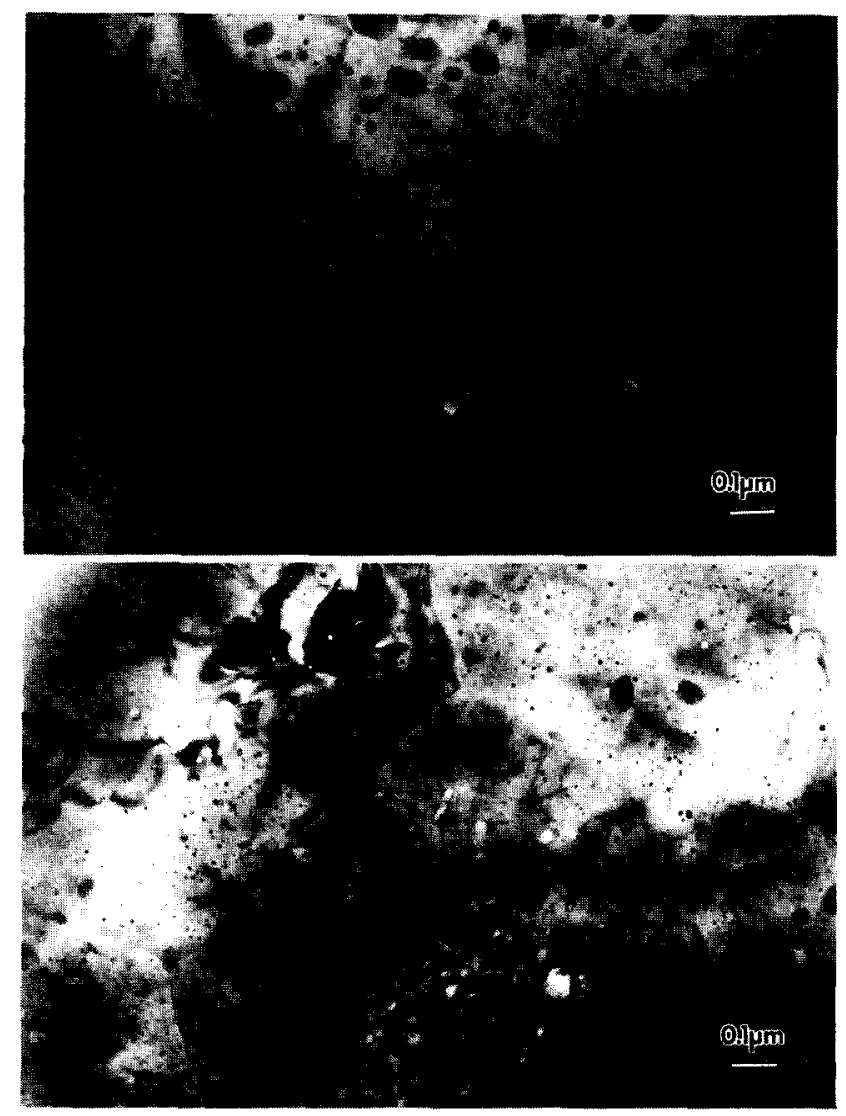

Fig. 10. TEM micrographs of GD-ZMC samples with (a) $9 \mathrm{vol} \%$ and (b) $3 \mathrm{vol} \%$ of $\mathrm{ZrO}_{2}$ sintered at $1400^{\circ} \mathrm{C}$ for $2 \mathrm{~h}$.

several times less than the size of mullite grains measured in a pure aluminosilicate gel system. ${ }^{6}$ However, the mullite grows to a larger size if sintered at a higher temperature or the composition contains less $\mathrm{ZrO}_{2}$. Figure 10 presents TEM micrographs of GD-ZMC samples containing either 9 or 3 vol $\% \mathrm{ZrO}_{2}$. Their $\mathrm{ZrO}_{2}$ grains are mostly intragranular, and have an average grain size, 30 or $9 \mathrm{~nm}$, which is several times less than that of GD-ZMC with $24 \mathrm{vol}^{\%} \mathrm{ZrO}_{2}$. The mullite grains in Fig. 10 grew to larger size, near $1 \mu \mathrm{m}$, and had straight grain boundaries. The dragging of mullite grain boundaries by $\mathrm{ZrO}_{2}$ grains is apparently dependent upon the volume fraction and size of the $\mathrm{ZrO}_{2}$, which is similar to the behaviour reported by Lange and Hirlinger ${ }^{20}$ and Prochazka et $a .^{9}$ An illustrative example, i.e. the $1300^{\circ} \mathrm{C}$ sintered GD-ZMC sample, is given in Fig. 8; the mullite grains exhibit crooked boundaries which trap several larger $\mathrm{ZrO}_{2}$ grains (larger than the average size of intragranular $\mathrm{ZrO}_{2}$ ). This demonstrates the likelihood that the growth of mullite grains is inhibited by $\mathrm{ZrO}_{2}$ grains.

\subsection{Grain growth of zirconia and mullite}

The results of previous SEM and TEM micrographs are reported in Fig. 11, from which it can be seen that the grain sizes of mullite and $\mathrm{ZrO}_{2}$ in 

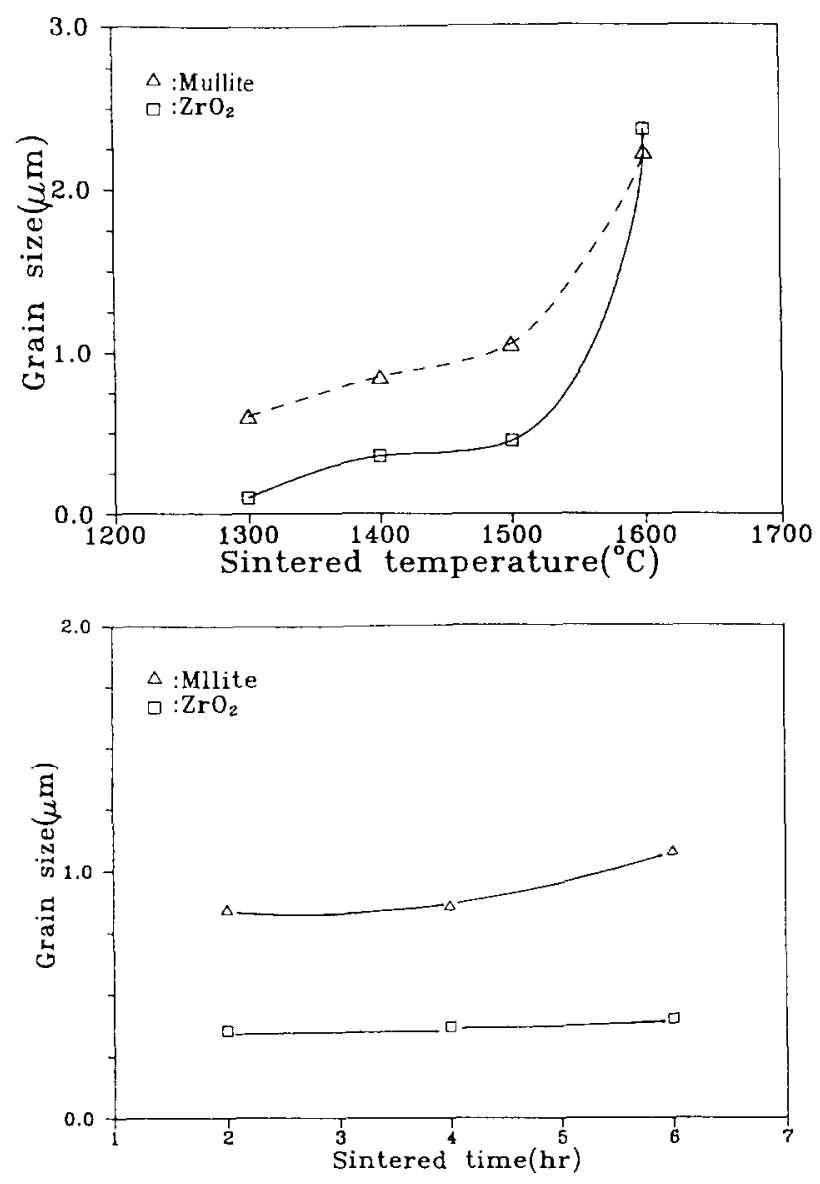

Fig. 11. Grain sizes of mullite and intergranular $\mathrm{ZrO}_{2}$ in various GD-ZMC samples with $24 \mathrm{vol} \% \mathrm{ZrO}_{2}$ : (a) sintered at 1300 to $1600^{\circ} \mathrm{C}$ for $2 \mathrm{~h}$; (b) sintered at $1400^{\circ} \mathrm{C}$ for 2 to $6 \mathrm{~h}$.

various gel-derived $\mathrm{ZMCs}$ increase as the sintering temperature and sintering time increase. The application of Zener's relationship ${ }^{21}$ to the above cases illustrates the relationship between the mean grain radius $(R)$ of the mullite matrix, the mean radius $(r)$ of the $\mathrm{ZrO}_{2}$ inclusions and the volume fraction $(f)$ of the inclusion:

$$
R=4 r /(3 f)
$$

This relationship provides a calculated $R$ value for the $1400^{\circ} \mathrm{C}$-sintered GD-ZMC that is comparable with the measured $R$ (Table 2 ). However, the measured mullite grain size increases as the amount of zirconia decreases, and the zirconia inclusions are not all spherical and uniformly distributed (Fig. 10 ), leading to differences between measured and calculated $R$ values. In addition, the relationship does not hold true for mullite grains in the GD-

Table 2. Calculated and measured mean radius $(R)$ of mullite in GD-ZMC determined from the volume fraction $(f)$ and grain radius $(r)$ of zirconia phase

\begin{tabular}{lccc}
\hline $\mathrm{f}$ & $\mathrm{r}(\mathrm{nm})$ & Calculated R $(\mathrm{nm})$ & Measured R $(\mathrm{nm})$ \\
\hline 0.24 & 49 & 272 & 300 \\
0.09 & 15 & 222 & $\sim 600$ \\
0.03 & 4.5 & 200 & $\sim 750$ \\
Pure mullite $^{22}$ & - & - & $\sim 1250$ \\
\hline
\end{tabular}

ZMC sintered at temperatures $>1500^{\circ} \mathrm{C}$ [Fig. 11(a)]. The growth of the mullite grains is accompanied by the coarsening of $\mathrm{ZrO}_{2}$ inclusions. Two phases are growing inter-affected.

The second-phase $\mathrm{ZrO}_{2}$ in the mullite matrix can ripen either by Ostwald ripening or by coalescence. The processes are well documented in a similar ceramic composite system, ${ }^{5}$ in which Ostwald ripening is driven by the variation of solubility of $\mathrm{ZrO}_{2}$ with various particle sizes, and the composite grows larger $\mathrm{ZrO}_{2}$ particles at the expense of smaller $\mathrm{ZrO}_{2}$ particles. Coalescence of $\mathrm{ZrO}_{2}$ particles occurs by the dragging of matrix mullite boundaries. The phenomenological evidence for the former process was a particle-free zone at matrix grain boundaries despite the fact that the diffusion rate along the mullite grain boundaries is faster than that in the mullite lattice. Alternatively, the latter case is particle clustering at grain boundaries. In this study, the micrographs revealed no grain boundary particle-free zone.

It was reported by Dinger et al. ${ }^{13}$ that a $2 \%$ solid solution of $\mathrm{ZrO}_{2}$ near interface grain boundaries of mullite has been detected. They sintered the sample at $1570^{\circ} \mathrm{C}$ for 2 to $16 \mathrm{~h}$. Mullite with an extensive amount of zirconia solid solution should be expected at temperature $>1570^{\circ} \mathrm{C}$. But a quite controversial result was reported later by the same research group, ${ }^{10}$ that $>20 \mathrm{wt} \%$ of $\mathrm{ZrO}_{2}$ was found in the mullite grains. This seems not to be the case for our ZMC. Figure 12 shows a DZ-ZMC sample that has been sintered at $1700^{\circ} \mathrm{C}$ for $30 \mathrm{~min}$. The zirconia grains either intergranularly or intragranularly are of size $50 \mathrm{~nm}$ to $3.5 \mu \mathrm{m}$, as shown in Fig. 12. Scanning transmission electron microscopy with micro-beam EDS analysis reveals that the ZMC has a non-detectable zirconia concentration in the mullite grains, as shown in the EDS spectra obtained from spots 2 and 4 . That implies that no zirconium forms a solid solution in mullite. This finding is consistent with the recent measurement given by Moya $^{23}$ that $<0 \cdot 1 \mathrm{wt} \%$ zirconia solid solution is measured in zirconia-toughened mullite. This implies that ripening through grain boundary diffusion was not occurring in ZMC. Many intergranular $\mathrm{ZrO}_{2}$ particles are actually in the form of clustering at triple grain boundaries, and exhibit larger grain size. We believe that such particle clustering is good evidence for coarsening by the coalescence of $\mathrm{ZrO}_{2}$. The zirconia in GD-ZMC is apparently ripening intergranularly while being treated above $1300^{\circ} \mathrm{C}$ in this experiment.

\section{Summary}

Three types of ZMC prepared either from gel 

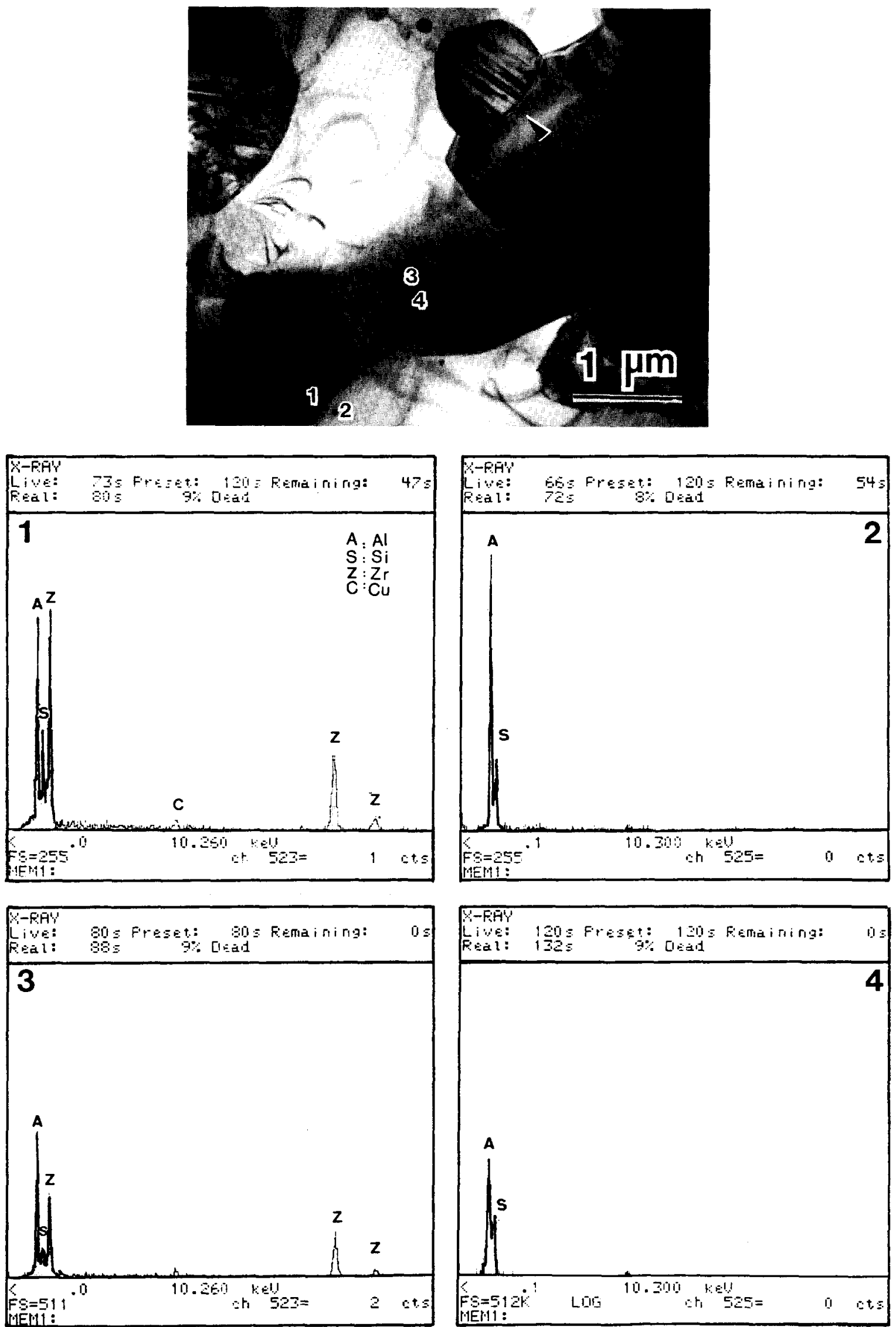

Fig. 12. TEM BF micrograph and EDX results of the intergranular and intragranular zirconia grains (1 and 3 ) and their mullite neighbourhood (2 and 4). The DZ-ZMC was sintered at $1700^{\circ} \mathrm{C}$ for $30 \mathrm{~min}$.

precursors or solid powder mixtures were investigated in this study. Quantitative analysis on the micro-structural evolution of $\mathrm{ZrO}_{2}$ and mullite matrix grains was conducted, and correlated with the processing temperature and the content of $\mathrm{ZrO}_{2}$. 
The solid solution of $\mathrm{ZrO}_{2}$ in the mullite matrix was undetected and $\mathrm{ZrO}_{2}$ particle-free zones were not observed in the GD- and DZ-ZMC samples, including the one with the longest heat treatment $\left(1600^{\circ} \mathrm{C}\right.$ for $\left.24 \mathrm{~h}\right)$. This implies that the growth of $\mathrm{ZrO}_{2}$ grains in mullite matrix cannot procecd via the process of Ostwald ripening. Grain clustering of intergranular $\mathrm{ZrO}_{2}$ was observed, suggesting the coalescence of the $\mathrm{ZrO}_{2}$ can occur at temperatures above $1300^{\circ} \mathrm{C}$. Coarsening of intergranular and intragranular $\mathrm{ZrO}_{2}$ particles in the mullite matrix is triggered by the mullite grain growth. The dragging of mullite grain boundaries by $\mathrm{ZrO}_{2}$ is apparent for samples sintered at temperatures of $1400^{\circ} \mathrm{C}$ and above. The relationship between the grain growth of mullite and the volume fraction and size of $\mathrm{ZrO}_{2}$ inclusions can be verified, but not well described by Zener's equation.

The advantages of the gel-process over reaction-sintering to prepare ZMCs with fine microstructure are clearly revealed in this work. A lower sintering temperature offers a higher densification rate and smaller grain sizc, thercby resulting in more $t$-phase zirconia and smaller grain size of mullite.

\section{Acknowledgement}

This work was supported by National Science Council in Taiwan under contract numbers NSC 81-0405-E002-25 and 82-0405-E002-245.

\section{References}

1. Claussen, N. \& Ruhle, M., Design of transformationtoughened ceramics. In Science and Technology of Zirconia III, Advances in Ceramics, Vol. 24, eds S. Somiya, N. Yamamoto \& H. Yanagida, The American Ceramics Society, Westerville, $\mathrm{OH}, 1988$, p. 137.

2. Lange, F. F., Low thermal conductivity silicon nitride/ zirconia composite ceramics. US Patent $4640902,3 \mathrm{Feb}$. 1987.

3. Rincon, J. M. \& Moya, J. S., Microstructural study of toughened $\mathrm{ZrO}_{2} /$ mullite ceramic composition obtained by reaction sintering with $\mathrm{TiO}_{2} . B r$. Ceram. Trans. J., 85 (1986) 201-6.

4. Garvie, R. C., Improved thermal shock resistant refractories from plasma-dissociated zircon. J. Mater. Sci., 14 (1979) 817-22.

5. Kibbel, B. W. \& Heuer, A. H., Ripening of inter- and intragranular $\mathrm{ZrO}_{2}$ particles $\mathrm{ZrO}_{2}$-toughened $\mathrm{Al}_{2} \mathrm{O}_{3}$. In
Science and Technology of Zirconia II, Advances in Ceramics, Vol. 12, The American Ceramics Society, Westerville, OH, 1984, pp. 415-24.

6. Wei, W., Ph. D. Thesis, Case Western Reserve University, July 1986.

7. Wallace, J. S., Petzow, G. \& Claussen, N., Microstructure and property development of in situ-reacted mullite- $\mathrm{ZrO}_{2}$ composites. In Science and Technology of Zirconia II, Advances in Ceramics, Vol. 12, The American Ceramics Society, Westerville, OH, 1984, pp. 436-42.

8. Descamps, P., Sakaguchi, S., Poorteman, M. \& Cambier, F., High-temperature characterization of reaction-sintered mullite-zirconia composites. J. Am. Ceram. Soc., 74(10) (1991) 2476-81.

9. Prochazka, S., Wallace, J. S. \& Claussen, N., Microstructure of sintered mullite-zirconia composites. J. Am. Ceram. Soc., 66 (1983) C125-7.

10. Miranzo, P., Pena, P., de Aza, S., Moya, J. S., Ma Rinco, J. \& Thomas, G., TEM study of reaction-sintered zirconia-mullite composites with $\mathrm{CaO}$ and $\mathrm{MgO}$ additions. J. Mater. Sci., 22 (1987) 2987-92.

11. Leriche, A., Mechanical properties and microstructures of mullite-zirconia composites. In Mullite and Mullite Matrix Composites. Ceramic Transactions, Vol. 6, eds S. Somiya, R. F. Davis \& J. A. Pask, The American Ceramics Society, Westerville, OH, 1990, pp. 541-52.

12. Pena, P., Miranzo, P., Moya, J. S. \& dc Aza, S., Multicomponent toughened ceramic materials obtained by reaction sintering, Part I-System $\mathrm{ZrO}_{2}-\mathrm{Al}_{2} \mathrm{O}_{3}-\mathrm{SiO}_{2}-\mathrm{CaO}$. J. Mater. Sci., 20 (1985) 2011-22.

13. Dinger, T. R., Krishnan, K. M., Thomas, G., Osendi, M. I. \& Moya, J. S., Investigation of $\mathrm{ZrO}_{2} /$ mullite solid solution by energy dispersive X-ray spectroscopy and electron diffraction. Acta. Metall., 32(10) (1984) 1601-7.

14. Schneider, H., Transition metal distribution in mullite. In Mullite and Mullite Matrix Composites, Ceramic Transactions, Vol. 6, eds S. Somiya, R. F. Davis \& J. A. Pask, The American Ceramics Society, Westerville, OH, 1990, pp. $135-58$.

15. Ho, Y. F. \& Wei, W. J., Reaction sintering of zirconiamullite composites. In Proc. 1992 Annual Conf. Chinese Soc. for Mater. Sci., 24-26 April 1992, pp. 470-1.

16. Low, I. M. \& McPersonal, R., Crystallization of gel-derived mullite-7irconia composites. J. Mater. Sci, 24 (1989) $951-8$.

17. Shiga, H., Katayama, K., Tsunatori, H. \& Ismail, G. M. U., Sol gel synthesis and sintering of oxide-doped mullite$\mathrm{ZrO}_{2}$ composite powders. Ceram. Powder Sci. IV, (1990) 457-62.

18. Holmstrom, M., Chartier, T. \& Boch, P., Reactionsintered $\mathrm{ZrO}_{2}-$ mullite composites. Mater. Sci. Eng., A109 (1989) 105-9.

19. Mader, W., On the electron diffraction contrast caused by large inclusions. Phil. Mag. A, 55(1) (1987) 5983 .

20. Lange, F. F. \& Hirlinger, M. M., Hindrance of grain growth in $\mathrm{Al}_{2} \mathrm{O}_{3}$ by $\mathrm{ZrO}_{2}$ inclusion. J. Am. Ceram. Soc., 67(3) (1984) 164-8.

21. Reed-Hill, R. E., Physical Metallurgy Principles, Van Nostrand, Princeton, NJ, 1973, p. 138.

22. Wei, W. \& Halloran, J. W., Transformation kinetics of diphasic aluminosilicate gels. J. Am. Ceram. Soc., 71(7) (1988) 581-7.

23. Moya, J. S., Private communication, September 1994. 